\title{
CONSUMER REDRESS MECHANISMS IN MALAYSIA: PROSPECTS AND CHALLENGES*
}

\author{
Naemah Amin ${ }^{* *}$
}

\begin{abstract}
An efficient, inexpensive and informal redress machinery is indeed essential for attaining consumer protection. In this respect the ordinary court system in Malaysia is generally perceived to be unable to satisfy consumers' needs. Thus the establishment of the Tribunal for Consumer Claims in 1999 and the Tribunal for Homebuyer Claims in 2002 may be considered as two major landmarks in the development of consumer protection law in Malaysia. It is the aim of this paper to examine the current status of these two Tribunals, which shares many common features save for the jurisdiction. Although records show that the Tribunals have received tremendous response from consumers in Malaysia, there are yet many improvements to be made. In addition this paper examines the challenges faced by the Tribunals in the course of offering an informal, faster and cheaper procedure to consumers.
\end{abstract}

This article is a revised version of a paper presented at the $11^{\text {th }}$ International Conference on Consumer Law, Cape Town, South Africa, 11-13 April 2007.

Associate Professor, Ahmad Ibrahim Kulliyyah of Laws, International Islamic University Malaysia. 
Some of these major challenges are enforcement of the Tribunals judgement, accessibility, publicity and judicial review.

\section{INTRODUCTION}

A proper system of resolving consumer disputes is one of the most important components in consumer protection law. The ordinary court system which is not only expensive but time-consuming, worrisome and complex has been generally considered a failure and ineffective in dealing with consumer cases. ${ }^{1}$ Furthermore, most consumer claims consist of small claims with low value which can suitably be handled by a redress system that is comparatively simple, cheap and instant. Although such a claim may actually be brought to a Small Claims Court, this process appears to have several weaknesses particularly due to the fact that it operates within the ordinary court mechanism. Consequently, coupled with lack of publicity of its existence, consumers rarely resort to this redress.

Accordingly an alternative mode of dispute settlement was obviously needed to remedy the situation. The call for a proper redress system for consumers was finally answered by the government when it established the Tribunal for Consumer Claims in 1999 and followed by the Tribunal for Homebuyer Claims in 2002. ${ }^{2}$ The primary objective of establishing the Tribunals is to provide an alternative forum for consumers to settle their trade disputes in less cumbersome, speedy manner and at a minimal cost. A tribunal has been recognised as a method of alternative dispute resolution (ADR) besides arbitration, negotiation, mediation and the ombudsman. ${ }^{3}$ It is an independent body established under a specific

$1 \quad$ S. Sothi Rachagan, Consumer law reform - A report, United Nations Development Programme and Selangor and Federal Territory Consumer' Association, 1993, Chapter 8.

2 It should be noted that there are other specialised alternative disputes resolutions relevant to consumers such as the Financial Mediation Bureau, the Co-operative Tribunal and the Legal Aid Mediation Bureau. These are however excluded from the discussion due to limited space and time.

3 See for example H.J. Brown \& A.L. Marriott Q.C (1999), ADR Principles and Practice, Sweet \& Maxwell Ltd., London, p. 16. 
statute and its jurisdiction is confined to the matters that are prescribed by such statute. The establishment of these Tribunals also marked the fruition of long-standing efforts by many consumer organisations in Malaysia, notably the Federation of Malaysian Consumers Associations (FOMCA) in championing consumer protection. ${ }^{4}$

\section{JURISDICTION OF THE TRIBUNALS}

\section{The Tribunal for Consumer Claims}

The Tribunal for Consumer Claims (hereinafter referred to as "the TCC") was established under Part XII of the Consumer Protection Act 1999 (hereinafter referred to as "the CPA"). The TCC came into being on 15 November 1999, the same date the CPA was enforced. It is under the jurisdiction of the Ministry of Domestic Trade and Consumer Affairs. The primary function of the TCC is to hear and determine claims filed by consumers under the CPA. ${ }^{5}$ This includes a claim relating to supply of goods, supply of services and unfair trade practices such as misleading advertisements, misleading price indications etc., provided that the claim does not exceed RM25,000. In addition, the TCC may also entertain a consumer complaint under other statutes within the purview

$4 \quad$ Mohd. Hamdan Adnan (2003), Perjuangan Perundangan Pengguna, ibsBUKU, Kuala Lumpur.

5 A consumer is defined in section 3(1) of the CPA as a person who:

“(a) acquires or uses goods or services of a kind ordinarily acquired for personal, domestic or household purpose, use or consumption; and

(b) does not acquire or use the goods or services, or hold himself out as acquiring or using the goods or services, primarily for the purpose of-

(i) resupplying them in trade;

(ii) consuming them in the course of a manufacturing process; or

(iii) in the case of goods, repairing or treating, in trade, other goods or fixtures on land." 
of the Ministry of Domestic Trade and Consumer Affairs such as hirepurchase transactions, direct selling and pyramid schemes. ${ }^{6}$

Arguably the TCC may also hear and determine consumer claims in other matters outside the CPA as long as it is not expressly excluded from its jurisdiction. Section 99 of the CPA provides a list of matters outside the jurisdiction of the TCC, namely;

(a) a claim for recovery of land, or any estate or interest in land;

(b) a claim in which the title to any land, or any estate or interest in land, or any franchise, is in question;

(c) disputes concerning -

(i) a will or settlement or intestacy;

(ii) goodwill;

(iii) any chose in action; or

(iv) any trade secret or other intellectual property;

(d) a claim under the jurisdiction of other tribunals; and

(e) a claim arising from personal injury or death.

The exclusion of the matters stated above is in line with the primary aim of the TCC which is to deal with only 'simple' and 'minor' consumer complaints. ${ }^{7}$ Matters such as intellectual property, franchise and estate claims are undoubtedly rather complicated. Similarly a claim for personal injury or death may not be properly and satisfactorily settled in a simplified procedure. On the other hand the exclusion has the effect of limiting the power of the TCC to deal with certain matters within the ambit of the CPA. This is particularly relevant with regard to product liability claims which normally involve personal injury. Although Part X of the CPA introduced a system of strict liability for defective products, most claims need to be filed in the ordinary courts. In addition the jurisdiction of the TCC is also restricted to a claim that is based on a cause of action which accrues within three years of the claim. ${ }^{8}$

$6 \quad$ Hire-purchase is governed by the Hire-purchase Act 1967 whereas a direct selling business and pyramid scheme is controlled by the Direct Sales Act 1993.

7 See Parliamentary Debates [1999] Vol.5 No. 30.

8 Section 99(2) of the CPA. 


\section{The Tribunal for Homebuyer Claims}

The Tribunal for Homebuyer Claims (hereinafter referred to as "the THC") was established under the Housing Development (Control and Licensing) Act 1966 (hereinafter referred to as "the HDA") as part of major revamp to the Act in 2002. The amendment aimed at providing better protection to house buyers in Peninsular Malaysia. ${ }^{9}$ Part VI was newly included in the amendment which established the THC and came into operation on $1^{\text {st }}$ December 2002. It is one of the agencies under the jurisdiction of the Ministry of Housing and Local Government. The main function of the THC is to resolve complaints on housing-related problems which have been a major consumers' complaint in Malaysia for the past many years. However the THC's jurisdiction is restricted to claims made by homebuyers, ${ }^{10}$ the amount of which does not exceed RM50,000 ${ }^{11}$

The type of claim that can be filed in the THC is divided into two, technical and non-technical. A technical claim includes claims relating to unsafe structure and poor workmanship, lack of basic amenities and non-compliance with the housing specification stated in the sale and purchase agreement. A common example of a non-technical claim is the claim for compensation for late delivery of vacant possession of a house. Prior to the 2007 Amendment, housing-related complaints caused by an abandoned project were beyond the THC's jurisdiction. Section 16N(2) of the HDA previously provided that a claim must be filed in the THC not later than 12 months from the date of the issuance of the certificate of completion and compliance ${ }^{12}$ or the expiry date of the defects liability

9 For further discussion on the 2002 Amendment see Samsar Kamar Abdul Latif (2002), 'New provisions on Housing Developers (Control and Licensing) (Amendment) Act 2002', INSAF, The Journal of Malaysian Bar, Vol. xxxi.

10 Section 16A of the HDA defines a homebuyer as a purchaser who has bought a property or has dealing with a licensed housing developer. This also includes the second purchaser who purchased the property from the first purchaser under a sub-sale.

11 The Housing Development (Control and Licensing) (Amendment) Act 2007 (hereinafter referred to as the 2007 Amendment).

12 Formally known as the certificate of fitness for occupation. The term has been changed and redefined in the 2007 Amendment to the HDA. 
period. ${ }^{13}$ Thus any claim for a housing project abandoned by the developer would be considered as pre mature since a cause of action can only arise under the provision after the project is completed.

However the recent amendment to section $16 \mathrm{~N}(2)$ provides that a homebuyer may also file a case in the THC not later than 12 months from "the date of termination of the sale and purchase agreement by either party and such termination occurred before the date of issuance of the certificate of completion and compliance.” The requirement of section $16 \mathrm{~N}(2)$ also has the effect of reducing the limitation period to bring a case to the THC to less than three years. ${ }^{14}$ Based on the same provision, the jurisdiction of the THC is also limited to a claim that is based on a cause of action arising from a sale and purchase agreement entered into between the homebuyer and the licensed housing developer. Consequently unlicensed developers and other parties in the construction industry such as contractors, engineers and architects cannot be sued in the THC. Additionally all matters excluded from the jurisdiction of the TCC as listed in section 99 of the CPA are effectively excluded from the jurisdiction of the THC. ${ }^{15}$

\section{PROCEDURES AND AWARDS}

Both Tribunals provide similarly simple, cheap and informal procedures. ${ }^{16}$ A claimant may lodge his claim by completing a specific form which can be obtained free from the Tribunals. The filing fee is only RM5 for the TCC and RM10 for the THC but the claimant needs to serve the claim to the respondent either personally or through registered post. A respondent who disputes the claim must file his defence together

The present defect liability period is 18 months. See Clause 26 and 30 of Schedules G and H of the Housing Development Regulations. The phrase "whichever is later" has been added to the section in the 2007 Amendment.

14 Notably the limitation period for contractual claim is six years under section 6 of the Limitation Act, 1960.

15 Section $16(\mathrm{~N})(1)$ and section $16 N(4)$ of the HDA.

16 See The Consumer Protection (the Tribunal for Consumer Claims) Regulations, 1999 and the Housing Development (Tribunal for Homebuyer Claims) Regulations, 2002. 
with counter-claim (if any) within 14 days after the service of the statement of claim. ${ }^{17}$ The Tribunals will then issue a notice of hearing to both parties not less than 14 days before the date of hearing. However before a proper trial is conducted, the Tribunals would asses whether it is appropriate for the parties to negotiate an agreed settlement in relation to the claim. ${ }^{18}$ Providing a room for disputes to be settled in two-party negotiations between claimant and respondent with less involvement of the tribunals will undoubtedly make the process not only simpler and faster but exemplifies the true spirit of the ADR concept.

An agreed settlement by the parties shall be approved, recorded and regarded as an award of the Tribunals. Alternatively, the Tribunals will proceed to determine the dispute if it appears that it would not be appropriate for the Tribunals to assist the parties to a negotiation or when such negotiation process has failed. A proper hearing is then conducted in a 'court set-up' room but the parties are not allowed to be represented by an advocate and solicitor. ${ }^{19}$ At the hearing the parties are entitled to adduce evidence, call any witness or produce any document and other relevant information in support of their case. All proceedings before the Tribunals are open to the public. The hearing of the Tribunals may thus be regarded as a 'simplified version' of the ordinary court procedure.

The length of time the Tribunals will take to resolve a claim depends on several factors. These include the number of cases filed at a particular time, the nature and complexity of cases and efficiency in servicing relevant documents or notices. Despite these factors, the Tribunals are required to make the decisions or awards without delay and, where practicable, within sixty days from the first day the hearing commences. ${ }^{20}$ To serve this purpose, the Tribunals will normally proceed

17 If there is a counter-claim the claimant may file a defence to such counter-claim in a prescribed form.

18 Section 107 of the CPA and section $16 \mathrm{~T}$ of the HDA.

19 It should be noted that a corporation or an unincorporated body may be represented by its full time employee who may well be a lawyer. In such a case, the Tribunals may impose necessary conditions to ensure the other party is not substantially disadvantaged. See section 108 of the CPA and section 16U(2) of the HDA respectively. A party may also be represented by a lawyer in the THC if in the opinion of the Tribunal the claim involves complex issues of law.

20 Section 112 (1) of the CPA and section 16Y(1) of the HDA. 
to hear and determine the claim notwithstanding the absence of any party to the proceedings as long as a notice of the hearing has been duly served on the absent party. The Tribunals are more likely able to settle claims in a speedy manner as they hardly deal with substantive law and decisions are entirely based on facts presented before them. However the Tribunals are required to give reasons for the awards. ${ }^{21}$

In addition to requiring the respondent to pay damages to the claimant, the Tribunals are empowered to make other forms of awards. The TCC may order the respondent to supply or resupply the goods, or to repair or replace the goods, or to refund the price or other consideration paid by consumers. The respondent may also be asked to comply with express or implied guarantees with regard to a supply of goods or services under the CPA. ${ }^{22}$ On the other hand, an award of the THC may consist of an order that a party complies to the sale and purchase agreement or the contract to be varied or set aside. Although the Tribunals are meant to protect consumers, an award of the Tribunals includes a dismissal of the claim. The Tribunals however are not empowered to award any damages for any non-pecuniary loss or damage. ${ }^{23}$ The decisions of the Tribunals are final and shall be deemed to be an order of a Magistrate's Court. A party against whom any order has been made by the Tribunals must comply with the order within a period specified in the order after the decision is made. ${ }^{24}$ Failure to comply with such order amounts to an offence and the defaulting party may be subjected to a criminal penalty. ${ }^{25}$

\footnotetext{
21 Section 114 of the CPA and section 16AA of the HDA.

22 Section 112(2) of the CPA.

23 Section 112 (3) of the CPA and section 16Y(3) of the HDA.

24 Section $117(1)$ of the CPA provides specified period of 14 days to comply with the TCC's awards but the THC has discretion on the matter.

25 The punishment for failure to comply with the TCC's awards is a fine not exceeding five thousand ringgit or imprisonment for a term not exceeding two years or both. In the case of a continuing offence, the offender will be liable to a fine not exceeding one thousand ringgit for each day or part of the day during which the offence continues after conviction. The corresponding section of the HDA has been amended (2007 Amendment) to increase the fine to a minimum of five thousand ringgit and maximum of ten thousand ringgit.
} 


\section{THE TRIBUNALS - PRESENT POSITION}

The Tribunals have received considerably good response from the public and the number of claims filed by consumers particularly at the TCC has increased over the years. As shown in Table 1, from only 291 cases recorded in 2000 when it commenced its operation, the number of complaints have risen substantially. On the other hand, Table 1 also shows some reduction in the number of cases filed in the THC for the past two years. However whether this is a true reflection of the effectiveness of the 2002 Amendment of the $\mathrm{HDA}^{26}$ or the decreasing number of housing problems faced by homebuyers is uncertain.

Table 1 - Cases filed in the Tribunals 2000-200627

\begin{tabular}{|l|c|c|c|c|c|c|c|}
\hline \multicolumn{1}{|c|}{ Year } & $\mathbf{2 0 0 0}$ & $\mathbf{2 0 0 1}$ & $\mathbf{2 0 0 2}$ & $\mathbf{2 0 0 3}$ & $\mathbf{2 0 0 4}$ & $\mathbf{2 0 0 5}$ & $\mathbf{2 0 0 6}$ \\
\hline $\begin{array}{l}\text { Tribunal } \\
\text { for } \\
\text { Consumer } \\
\text { Claim }\end{array}$ & 291 & 1155 & 2649 & 4150 & 5076 & 6106 & 7607 \\
\hline $\begin{array}{l}\text { Tribunal } \\
\text { for } \\
\text { Homebuyer } \\
\text { Claims }\end{array}$ & - & - & - & 3554 & 6523 & 5622 & 3710 \\
\hline
\end{tabular}

The efficiency of the Tribunals in resolving the claims is shown in Table 2 and Table 3 respectively. Since its operation in 2000 until 2004, the TCC was able to settle almost all cases filed in the Tribunal and only recently the TCC has recorded a small number of pending cases. Similarly the THC should be credited for its ability to resolve almost $90 \%$ of

\footnotetext{
26 Apart from the setting up of the THC, the 2002 Amendment of the HDA has tightened Malaysian housing law by improving protection for house buyers. The new law has undoubtedly caused a positive impact on developers.

$27 \quad$ Statistics issued by the Tribunal for Consumer Claims, Putra Jaya and the Ministry of Housing and Local Government at www.kpht.gov.my/ kpht/main.php.
} 
homebuyers' complaints for the past four years, taking into consideration the complexity of housing cases in comparison to cases filed at the TCC. It should be noted however that 'settled cases' in the statistics also include cases that have been withdrawn by consumers. This is particularly obvious with respect to the TCC where $20 \%$ to $40 \%$ cases have been withdrawn every year. However only a small percentage of cases were withdrawn from the THC and the number has been reduced over the years. A withdrawal of cases normally occurs when a respondent who has been served with a statement of claim offers a claimant an "out of Tribunal settlement." A claimant who agrees with the settlement can simply go to the Tribunals and inform the secretary that he is withdrawing the claim.

As discussed earlier the Tribunals have two methods of resolving the disputes, namely, by assisting the parties to negotiate an agreed settlement or by conducting a proper trial. The number of cases which have been settled by negotiation or through a process of trial in the TCC is shown in Table 2. Although more cases are settled after a proper hearing, the number of settlements through negotiation have shown a significant percentage. For example 29\% from the total number of settled cases in 2002 were resolved by negotiation. In other years, the percentage of cases settled through negotiation was between $12 \%$ and $18 \%{ }^{28}$ In most of the cases that have gone through proper trial, the Tribunals have decided in favour of consumers. In other words, a very small percentage of cases were dismissed by the Tribunals ${ }^{29}$ and this normally happens either because the claim was unfounded, there was lack of evidence or the problem was caused by the consumer's own fault.

29 For example the statistics of status of cases filed in the TCC in 2006 show that only $3.64 \%$ of total cases filed from January to July were dismissed. 
Table 2 - Status of claims in the Tribunal for Consumer

Claims 2000-2006

\begin{tabular}{|c|c|c|c|c|c|c|c|c|}
\hline \multirow{2}{*}{ Year } & \multirow{2}{*}{$\begin{array}{c}\text { Number } \\
\text { of Claims }\end{array}$} & \multicolumn{2}{|c|}{ Type of Claims } & \multicolumn{3}{|c|}{ Method of Settlement } & \multirow[t]{2}{*}{ Settled } & \multirow[t]{2}{*}{ Balance } \\
\hline & & Goods & Services & Withdrawn & Negotiation & Trial & & \\
\hline 2000 & 291 & 221 & 70 & 107 & 55 & 129 & 291 & 0 \\
\hline 2001 & 1155 & 821 & 334 & 225 & 340 & 590 & 1155 & 0 \\
\hline 2002 & 2649 & 1489 & 1160 & 1088 & 495 & 1066 & 2649 & 0 \\
\hline 2003 & 4150 & 2284 & 1866 & 1683 & 539 & 1928 & 4150 & 0 \\
\hline 2004 & 5076 & 2781 & 2295 & 2029 & 556 & 2489 & 5076 & 0 \\
\hline 2005 & 6106 & 3762 & 2344 & 2667 & 579 & 2860 & 6106 & 0 \\
\hline 2006 & 7607 & 4109 & 3498 & 2719 & 750 & 2717 & 6186 & 1421 \\
\hline
\end{tabular}

Source - the Tribunal for Consumer Claims, Putra Jaya

In relation to types of cases filed in the TCC, Table 2 indicates that initially the Tribunal was dominated by complaints relating to goods. For example more than $70 \%$ of cases filed in 2000 and 2001 were supply of goods' claims. However complaints relating to services have significantly increased over the years since 2002. Presently the TCC deals with an almost equal number of cases concerning goods and services. Topping the list of complaints relating to goods are cases of 'forced sale' through a deceptive method known as 'scratch and win.' ${ }^{30}$ Other cases relate to quality of goods especially vehicles, mobile phones, electrical goods and computers. On the other hand, major complaints on services by the Chairman of the TCC, Rungit Singh reported in KOSMO, $3^{\text {rd }}$ April 2007, p. 20. 
are against travel agents, mechanics, private higher educational institutions and agencies for domestic helpers. ${ }^{31}$ Although statistics on types of complaints in the THC are not available for analysis, it is a well known fact that in the majority of cases filed (more than 80\%) there are claims for liquidated ascertained damages (LAD) as a result of late delivery of vacant possession of a house. ${ }^{32}$

Table 3 - Status of claims in the Tribunal for Homebuyer Claims 2003-2006

\begin{tabular}{|c|c|c|c|c|}
\hline Year & Number of Qlaims & Withdrawn & Settled & Pending \\
\hline 2003 & 3554 & 483 & 3548 & 6 \\
\hline 2004 & 6523 & 480 & 6346 & 177 \\
\hline 2005 & 5622 & 173 & 5257 & 365 \\
\hline 2006 & 3710 & 162 & 2258 & 1452 \\
\hline Total & 19409 & 1298 & 17409 & 2000 \\
\hline
\end{tabular}

Source - the Tribunal for Homebuyer Claims, the Ministry of Housing and Local Government, Kuala Lumpur.

\section{CHALLENGES}

In the course of offering an informal, faster and cheaper procedure to consumers, the Tribunals inevitably face some challenges that may affect their credibility in the eyes of the general public. Some of these challenges stem from a lacuna in the legal framework of the Tribunals' existence and functions. As a government agency, the Tribunals may also be affected by financial constraints, support systems and other

\footnotetext{
$31 \quad$ Rungit Singh, Ibid.

32 Information supplied by the statistic officer of the THC, Kuala Lumpur.
} 
bureaucratic problems. Other challenges result from different perception of consumers and traders towards the Tribunals. The majority of consumers look to the Tribunals as avenues to seek justice and they regard it with high expectations and veneration. Some traders on the other hand regard the tribunal as a government body with 'less power' than the ordinary court. Consequently they have shown their disrespect by simply ignoring the call for a hearing or the award of the Tribunals. ${ }^{33}$ This discussion however focuses on the main challenges presently faced by the Tribunals which include an enforcement of the judgement, accessibility, publicity, judicial review and efficiency.

\section{Enforcement of award}

Although awards of the Tribunals are final and binding on both parties, the Tribunals have no power to enforce the awards. The enforcement of the award is the responsibility of the winning party. ${ }^{34}$ Consequently in cases where the respondent fails to comply with the award, the claimant himself would have to go to the ordinary court for execution of the order. In practical reality, this causes difficulty to consumers since the execution procedure under the Subordinate Courts Rules 1980 is not a simple process. ${ }^{35}$ As a result some consumers never obtain their compensation at all. The THC has taken a positive step to reduce non-compliance of the award by allowing housing developers to pay damages by installments. Despite this alternative, the cases of failure to comply with the THC's awards have increased over the years as shown in Table 4.

33 The TCC has recorded a significant percentage of 'judgement in default' cases; 998 cases (23.67\%) in 2003, 1,216 cases (23.27\%) in 2004, 1,245 (20.31\%) in 2005 and 1,550 cases (20.51\%) in 2006.

$34 \quad$ Section 116(1)(b) of the CPA and section 16AC(b) of the HDA.

35 Execution of the order may be done through a writ of seizure and sale or specific performance depending on the forms of order awarded by the Tribunals. 
Table 4 - Cases of failure to comply with the THC’s awards 2003-2006

\begin{tabular}{|l|l|l|c|}
\hline \multicolumn{1}{|c|}{ Year } & \multicolumn{1}{c|}{$\begin{array}{c}\text { Number of } \\
\text { Cases }\end{array}$} & $\begin{array}{c}\text { Amount of Claims } \\
\text { (RM) }\end{array}$ & Number of Developers \\
\hline 2003 & 132 & 853,826 & 31 \\
\hline 2004 & 410 & $3,581,914.87$ & 81 \\
\hline 2005 & 1000 & $13,115,779.59$ & 114 \\
\hline 2006 & 910 & $9,814,945$ & 102 \\
\hline Total & 2452 & $28,454,484.34$ & 328 \\
\hline
\end{tabular}

Source - the Tribunal for Homebuyer Claims, the Ministry of Housing and Local Government, Kuala Lumpur.

Although a percentage of cases of non-compliance with the awards are only about $12 \%$ of the total number of cases filed in the Tribunals so far, it arguably, may have an impact on consumers' confidence on the Tribunals. Thus the enforcement of a criminal penalty on a person who has failed to comply with the Tribunals' award may be seen as a practical solution to this problem although it does not necessarily guarantee consumers in getting their damages. The Tribunal's duty in this respect is only to record complaints on non-compliance and forward it to the enforcement division for the purpose of prosecution. Table 5 shows the status of cases of failure to comply with the TCC's awards and it indicates that only half of the cases have already been filed in the courts. A smaller number of prosecutions are recorded by the legal unit of the Ministry of Housing and Local Government. Out of 2452 cases of non-compliance, only 298 charges were registered before the court up to August 2006 and in a few cases, punishments have been imposed. ${ }^{36}$

$36 \quad$ See list of developers who failed to comply with the THC's awards that have been charged in the court as of the $1^{\text {st }}$ August 2006 at www.kpht.gov.my/kpht/main.php. 
Table 5 - Cases of failure to comply with the awards of the TCC from 2000-Ogos 2006

\begin{tabular}{|c|c|c|c|c|}
\hline $\begin{array}{c}\text { Total number of } \\
\text { cases }\end{array}$ & $\begin{array}{c}\text { Cases filed in } \\
\text { the court }\end{array}$ & $\begin{array}{c}\text { Cases yet to be } \\
\text { filed }\end{array}$ & $\begin{array}{c}\text { Cases on } \\
\text { trial }\end{array}$ & Settled \\
\hline 2424 & 1213 & 1211 & 226 & 313 \\
\hline
\end{tabular}

Source - Enforcement Division of the Ministry of Domestic Trade and Consumer Affairs, Putra Jaya.

\section{Accessibility}

Section 85 of the CPA states that "there shall be established a tribunal to be known as the "Tribunal for Consumer Claims" and similar provision for the establishment of the Tribunal for Homebuyer Claims can be found in section 16A of the HDA. This means that only one TCC and THC at national level need to be established. The Tribunals will then have sittings throughout the country to hear consumer or homebuyer claims. The chairman, deputy chairman and other members of the Tribunals will then move around the country chairing one man tribunals to hear cases in two or more sittings on such day and at such time and place as the Chairman may determine. ${ }^{37}$ In this respect the TCC so far has sat in each major town all over Malaysia. However the THC only sits in Kuala Lumpur and only in a few occasions it has sat outside the capital city depending on the number of case filed at that particular place.

As a result, the Tribunals are actually accessible only to consumers in big urban areas such as Kuala Lumpur, Shah Alam and Penang and other state capitals. Consumers in rural areas would have to go to the nearest major town to file their case and this would mean that they may have to take a day's leave and forfeit wages for that day since most of them are self-employed. In addition they have to pay for their own transportation and other miscellaneous expenses. Obviously the 
current tribunal setup has not created an increase of accessibility to justice for rural consumers whereas they face greater consumer problems with traders compared to urban consumers who have more choice and avenues for redress. Comparatively the problem may not be as critical with regards to homebuyers since most housing development projects are centered in urban areas and thus it is sufficient for the THC to be made available in the major towns.

\section{Judicial review}

Although the decisions of the Tribunals are regarded final on questions of fact, they may be subject to judicial review on questions of law. This procedure has been used by traders and developers to challenge the Tribunals' findings. However the exact number of judicial review cases is unknown as statistics are not available except for situations where the Tribunal is also named as a respondent. The number of cases decided by the TCC that have been subjected to judicial review is illustrated in Table 6 . The percentage is perhaps very small and the highest number was recorded in 2004 (1.01\%).

Table 6 - Judicial review of the TCC’s awards 2000-2006

\begin{tabular}{|c|c|c|c|c|c|c|c|c|}
\hline Year & $\mathbf{2 0 0 0}$ & $\mathbf{2 0 0 1}$ & $\mathbf{2 0 0 2}$ & $\mathbf{2 0 0 3}$ & $\mathbf{2 0 0 4}$ & $\mathbf{2 0 0 5}$ & $\mathbf{2 0 0 6}$ & Total \\
\hline $\begin{array}{l}\text { Number } \\
\text { of cases }\end{array}$ & 0 & 3 & 17 & 16 & 53 & 28 & 11 & 128 \\
\hline
\end{tabular}

Source - the Tribunal for Consumer Claims, Putra Jaya.

In Hazlinda Hamzah $v$ Kumon Method of Learning Centre, ${ }^{38}$ the TCC ordered the respondent to make a partial refund of the tuition fee paid by the claimant because the services rendered by the respondent was unsatisfactory. However the High Court quashed the tribunal's award on the ground that it had failed to provide written reasons for its award 
as required under section 114 of the CPA. The Tribunal also committed an error of law in ordering a partial refund of the consideration in the absence of a total failure of consideration. The claimant appealed to the Court of Appeal and the court decided that section 114 only requires the Tribunal to give reasons for its award and it need not necessarily be in writing. The Court of Appeal also ruled that the Tribunal had the power under section 112(2) to order a refund. Therefore there was no basis for the grant of certiorari. Gopal Sri Ram, JCA in delivering judgement of the court said;

"Being a specialist body, the Tribunal has been conferred with extraordinary power to do speedy justice for consumers. As such, its awards should not be struck down save in the rarest cases, where it has misinterpreted some provision of the Act in such a way to produce an injustice."

In Puncakdana Sdn Bhd v Tribunal for Homebuyer Claims, ${ }^{39}$ the High Court granted an order of certiorari to quash the awards handed down by the THC in respect of several claims lodged by homebuyers on the ground that the THC has no jurisdiction to hear claims arising from sale and purchase agreements entered into prior to 1st December 2002. The decision rendered the THC incapable of hearing claims based on agreements entered into before its establishment and consequently the THC had to suspend its operations for a few months while waiting for the appeal decision. Fortunately in Tribunal for Homebuyer Claims $v$ Westcourt Corp. ${ }^{40}$ the Court of Appeal took the view that the HDA is a piece of social legislation and hence its provisions should be given liberal and purposive interpretation. Based on this approach, Richard Malanjum, JCA in delivering judgement of the court declared;

"To limit therefore the jurisdiction of the Tribunal to claims based on sale and purchase agreements entered into after the appointed date would tantamount to restricting the jurisdiction of the Tribunal which Parliament never intended to do so. It is absurd in our view to say that Parliament 
proceeded to legislate for the establishment of the Tribunal well aware that it would only begin to serve its purpose a few years later since it would be inconceivable for claims to arise on breach of sale and purchase agreements entered into as recent as the appointed date.”

This judgement was later upheld in the Federal Court and the Federal Court ruled that the provisions on the THC provide for a change of forum from the court to the Tribunal and this is a matter of procedure and not a matter of substantive right. It therefore operates retrospectively. ${ }^{41}$

Haslinda and Westcourt illustrates the current stand of the highest court in Malaysia on the issue of judicial review of the Tribunal's awards. Although the decisions appear favourable to consumers and the Tribunals, they do not deter traders and developers particularly 'repeat offenders' who are backed by huge financial resources and legal experts from challenging the awards. On the other hand, consumers who are dragged into the process may not be able to defend themselves without assistance from lawyers or consumer associations. For the same reason, judicial review will not be used by consumers although there are instances where the Tribunal's awards were not in their favour or they are not satisfied with the decisions and there is no other way for them to challenge the awards.

\section{Publicity}

Statistics from 2003 until 2006 indicate that an average of 5000 claims were heard by the Tribunals every year. Out of a total population of 25 million, it is perhaps an insignificant number. Whether this is a true reflection of the number of problems faced by consumers throughout the country is uncertain. As discussed earlier, the problem of accessibility to the Tribunals is definitely one of the factors contributing to such a small number of claims. Another factor is due to the fact that many Malaysians are still unaware and some are even 'illiterate' on consumer rights 
particularly among the rural folk. This results in them not being aware of their rights and the existence of the Tribunals. Table 7 shows that majority of the claims filed in the Tribunals are in big urban areas such as Kuala Lumpur, Shah Alam and Penang. Hence publicity needs to be seriously heightened to make consumers aware of the Tribunals' existence and functions.

Table 7 - Cases filed in the TCC and the THC according to states in 2006

\begin{tabular}{|l|c|c|}
\hline \multicolumn{1}{|c|}{ States } & $\begin{array}{c}\text { Tribunal for } \\
\text { Consumer Claims }\end{array}$ & $\begin{array}{c}\text { Tribunal for } \\
\text { Homebuyer Claims }\end{array}$ \\
\hline Kuala Lumpur & $\mathbf{2 5 1 4}$ & $\mathbf{9 3 1}$ \\
\hline Selangor & $\mathbf{1 0 2 4}$ & $\mathbf{1 5 7 9}$ \\
\hline Perak & 327 & 156 \\
\hline Negeri Sembilan & 327 & 60 \\
\hline Melaka & 352 & 153 \\
\hline Penang & $\mathbf{6 0 3}$ & $\mathbf{2 8 3}$ \\
\hline Kedah & 215 & 69 \\
\hline Johor & 494 & 208 \\
\hline Perlis & 62 & 1 \\
\hline Pahang & 338 & 192 \\
\hline Terengganu & 191 & 2 \\
\hline Kelantan & 91 & 76 \\
\hline
\end{tabular}

Source - the Tribunal for Consumer Claims, Putra Jaya and the Ministry of Housing and Local Government at www.kpht.gov.my/kpht/main.php.

\section{Efficiency}

The efficiency of any redress system is mainly judged by its ability to settle disputes in a speedy manner. The TCC and the THC have so far shown good performance in handling the claims. Nevertheless the number of pending cases has increased for the past two years as illustrated in Table 2 and Table 3. This may be caused by the increasing number of cases filed and the nature of cases which have become more complex and sometimes unpredictable. Thus practical steps need to be taken to prevent backlog of cases which will eventually affect the 
credibility and competency of the Tribunals. Additionally members of the Tribunals should be well acquainted with current market practices which are always subject to continuing and fast changes.

\section{PROSPECTS AND FUTURE DEVELOPMENT}

Undeniably the existence of the Tribunals has to some extent improved accessibility of consumers to justice and has created a climate of ethical trade throughout the nation. Looking at the present position of the Tribunals, it is most likely that the Tribunal for Consumer Claims will continue to receive more complaints from consumers for many years to come. Most claims will continue to be filed by urban and middle class consumers who are more knowledgeable and critical of their rights. On the other hand the introduction of 'build then sell' system may reduce the cases in the Tribunal for Homebuyer Claims since the problem of late delivery of vacant possession, which is currently the main complaint before the THC will no longer occur under the new system. However with the increase of its pecuniary jurisdiction to RM50,000, the THC may be faced with more complicated technical cases such as defective houses or non-compliance with specifications.

To maintain their efficiency, the Tribunals should be able to face current and future challenges by remedying weaknesses, improving accessibility and venturing into new methods of ADR. One approach to make the Tribunals more efficient is that parties should be encouraged to settle their disputes by negotiation. This 'non-confrontation' settlement is more in line with the true spirit of ADR and it may also save the Tribunals' time. The solution is perhaps more satisfactory for the claimant and the respondent since the parties will be in a win-win situation. However specific provisions on the procedure for negotiation have to be included in the CPA and the HDA. In addition certain peculiar features for a standard negotiation procedure such as confidentiality of the proceeding needs to be addressed.

To balance the flexibility given to corporations to be represented by a full time employee, who may well be an advocate and solicitor, a consumer should be allowed to be represented by a consumer organisation representative whether or not the consumer is a member of such an organisation. This is particularly important to assist consumers who are unable to bring their claim due to ignorance, helplessness, poverty or 
illiteracy. Another deficiency of the Tribunals is caused by their limited power and jurisdiction. Hence as a solution to the problem of noncompliance with the Tribunals' decision and the difficulty of enforcing the awards in the ordinary courts, the Tribunals should be given power to enforce their awards. ${ }^{42}$ Additionally, pecuniary jurisdiction of the Tribunals should be reviewed from time to time to be at par with the increased prices of goods and services. Similarly the limitation period of three years to bring a case in the TCC and less than three years for housing cases is clearly in conflict with the statute on limitations which provides a time limit of six years in filing contract and tort claims.

The present setup of the Tribunals particularly the TCC needs to be expanded to increase their accessibility to consumers. It has been suggested that the TCC should be established at Federal, State and District levels as practised in India for easy access and to reduce costs, particularly for rural consumers. ${ }^{43}$ It is possible that many more consumers will file their claims once they are aware that there is a TCC within their locality. To further increase consumer accessibility, the Tribunals should consider having sittings outside normal working hours for example in late evenings or even on weekends. Finally, but not less importantly, as the country heads further into the era of information technology, the Tribunals should also be responsive to modern innovations of using technologies in resolving disputes. ODR or Online Dispute Resolution, particularly using the internet, should thus be considered for future development of the Tribunals.

\section{CONCLUSION}

The problem of a redress mechanism can in fact be made simpler, quicker and less costly if any dispute can be settled in two-party negotiations between the consumer and the trader without any involvement of a third-party institution. Nevertheless the Tribunals may

\footnotetext{
42 As a matter of comparison, under section 25 of the Consumer Protection Act 1986 of India, the Consumer Disputes Redressal Agencies are given powers to enforce its own order.

43 Mohd. Hamdan Adnan (2005), Perjuangan Perundangan Pengguna, ibsBUKU, Kuala Lumpur, p. 40.
} 
be considered as the best redress mechanism presently available to Malaysian consumers. However continued assessment of the Tribunals' performance needs to be regularly made to ensure the effectiveness of their functions in providing informal, faster and cheaper procedures to consumers. To be able to function more efficiently, the current deficiencies of the Tribunals must be remedied and any inadequacy must be addressed. Continued assessment and improvement are very crucial for the Tribunals in gaining respect from both consumers and people in the industry. Most importantly the Tribunals cannot afford to lose consumers' confidence with their very purpose to offer justice to them. On the other hand the success of the Tribunals will also depend on the improvement of substantive legal protection to consumers, effective enforcement of the law as well as progressive level of consumer awareness. 